\title{
Hemolytic Anemia with Impaired Hexokinase Activity
}

\author{
Alan S. KeitT \\ From the Department of Medicine, University of Florida College of Medicine, \\ Gainesville, Florida 32601
}

\begin{abstract}
A в S T R A C T Analyses of key glycolytic intermediates in freshly drawn red cells from six related individuals suggest that decreased hexokinase activity underlies the hemolytic process in the two members with overt hemolysis. Low red cell glucose 6-phosphate (G6P) was observed not only in the anemic patients but in the presumptive heterozygotes as well and served as a useful marker for the presence of the trait. Hexokinase activity was labile in distilled water hemolysates but was only slightly low when protected by glucose, mercaptoethanol, and ethylenediaminetetraacetate (EDTA). Normal red cell hexokinase was demonstrated to be dependent on glucose for maintenance of activity after heating to $45^{\circ} \mathrm{C}$. The cells of the proposita are unable to utilize glucose efficiently at glucose concentrations lower than $0.2 \mathrm{mmole} / \mathrm{liter}$ whereas normal cells maintain linear glucose consumption to at least $0.05 \mathrm{~mm}$ glucose. These qualitative abnormalities could result from the presence of a mutant hexokinase with an abnormally reactive sulfhydryl group and altered substrate affinity in the red cells of this kindred.
\end{abstract}

\section{INTRODUCTION}

Hexokinase has recently been added to the growing list of glycolytic enzymes which have been found to have abnormal activity in the red cells of certain patients suffering from congenital nonspherocytic hemolytic anemia. Since hexokinase, as the first step in the glycolytic chain, has a putative role in the control of glycolytic rate in the red cell, an anomalous hexokinase is of interest to hematologist and biochemist alike. Valentine and his associates (1) have reported convincing evidence for hexokinase deficiency in the red

These studies were initiated at the Thorndike Memorial Laboratory, Boston City Hospital, Boston, Mass. 02118, continued at the Naval Blood Research Laboratory, Chelsea, Mass. 02150, and concluded at the University of Florida College of Medicine, Gainesville, Fla. 32601. A preliminary report of this work has been published in abstract form (7).

Received for publication 30 January 1969 and in revised form 16 May 1969. cells of a young girl with moderately severe chronic anemia. Although hexokinase activity was only slightly below the range of normal, a comparison between the activity of red cell hexokinase in the affected proposita and that in patients with diverse hemolytic anemias with comparably young cell populations greatly amplified the deficiency. The other members of the family had measured hexokinase activity which was similar to that of the patient except for one sibling with very low activity. None of these individuals had evidence of increased hemolysis.

This apparent lack of correlation between enzyme activity in broken cell systems and clinical severity has been a frequent finding among kindreds with congenital nonspherocytic hemolytic anemias associated with defective glycolytic enzymes. In addition to differences in mean cell age, several other factors may account for this phenomenon (2). Such mutant enzymes may be unduly labile and activity may be lost during preparation for assay even though the function of the enzyme may be adequate in the intact cell. Conversely, normal or increased activity may be obtained in the conventional assay procedure but because of kinetic abnormalities of an anomalous enzyme, there is a marked functional blockade in the intact cell with resultant hemolytic anemia $(3,4)$. It is probable that the majority of structural variants of catalytic proteins are not critically impaired either in activity or molecular stability and are clinically innocuous. Additional markers may be required to detect and define these complex disorders.

In all instances in which they have been properly measured, the glycolytic intermediates proximal and distal to an abnormal glycolytic enzyme associated with hemolytic anemia have shown marked deviations from normal (5). These abnormalities may persist despite apparent fluctuations in the activity of the enzyme on conventional assay (6) and serve as a useful criterion for the presence of a significant block along the main pathway of anaerobic glycolysis. Careful measurement of the glycolytic intermediates on freshly drawn and immediately deproteinized blood probably represents the best available information on the functional state of the glycolytic 
chain in the circulating red cell, and avoids many potential artifacts inherent in enzyme assay, purification, and electrophoresis.

This report concerns the second kindred with impaired red cell hexokinase atcivity and hemolytic anemia. In addition to demonstrating abnormalities in the glycolytic intermediates of anemic as well as hematologically normal family members, the glycolytic rate in intact cells and its dependence on glucose concentration has been studied in a controlled incubation system which is described in detail. These studies suggest that this kindred possesses an abnormal red cell hexokinase which is unduly labile in the absence of glucose. Some of these studies have been published previously in preliminary form (7).

Case report. The proposita is a $38 \mathrm{yr}$ old psychiatric nurse who has been intermittently jaundiced and mildly anemic since childhood. At the age of 20 , during nurse's training, she was hospitalized with presumptive hepatitis. At that time, her hematocrit was $38 \%$, reticulocyte count $1.8 \%$, total bilirubin $2.4 \mathrm{mg} / 100 \mathrm{ml}$, and a gallbladder X-ray was normal. She was discharged on oral iron, but because of continued jaundice, she was studied at the Lahey Clinic in Boston. The findings at this time were typical of hemolytic anemia, with reticulocytosis of $6.1 \%$, indirect bilirubinemia of $2.2 \mathrm{mg} / 100 \mathrm{ml}$, normoblastic hyperplasia of the bone marrow, and splenomegaly. The mean corpuscular volume was $120 \mu^{3}$ and the peripheral smear was predominantly macrocytic with sporadic microcytes, ovalocytes, and bizarre forms. Liver function was normal and a Coomb's test was negative. The osmotic fragility curve of fresh blood was normal but became skewed after incubation for $24 \mathrm{hr}$ with both fragile and resistant populations. Her hematocrit remained at about $36 \%$ with a reticulocyte count of
4-7\%. Because of intermittent left upper quadrant pain and persistent hemolysis, splenectomy was performed at age 23 resulting in disappearance of jaundice and an approximate doubling of the absolute reticulocyte count without change in her hematocrit. Her hematologic condition has not changed appreciably to date. Other pertinent laboratory data include a normal glutathione level of $65 \mathrm{mg} / 100 \mathrm{ml}$ of red cells, fetal hemoglobin of $3.1 \%$, authohemolysis comparable to a normal control both with and without glucose, and no visible Heinz bodies on supravital staining (postsplenectomy).

The sister of the proposita has also had periodic jaundice since birth and was studied at the Massachusetts General Hospital in 1947 without a definite diagnosis although congential nonhemolytic jaundice was thought likely. Her two daughters, ages 17 and 14, are in good health without known hematologic abnormalities. The mother, brother, and deceased father of the proposita had normal hematocrits and incubated osmotic fragilities in 1950. Current hematologic data on the family are shown in Table I.

\section{METHODS}

Enzyme assays. The hexokinase assay described by Valentine et al. (1) is not optimal for the abnormal hexokinase of the proposita. Preparation of hemolysates and freezethawing in the absence of glucose cause incremental losses of activity and induce kinetic abnormalities such that the adenosine triphosphate (ATP) concentration is partially limiting. Therefore, a modification of the system described by Chapman et al. (8) was used for most assays. Cells were prepared for assay by repeated centrifugation in saline containing phosphate buffer ( 5 mmoles/liter) and glucose (5 mmoles/liter) at $\mathrm{pH} 7.4$. Removal of the upper $5-10 \%$ of cells was essential since white cell contamination, particularly in deficient blood, is a major problem. After samples had been taken for red cell count (Coulter counter) and white

TABLE I

Hematological Features of the Kindred*

\begin{tabular}{|c|c|c|c|c|c|}
\hline & Proposita & Sister & Mother & Niece & Niece \\
\hline Hematocrit & 36 & 36 & 40 & 42 & 44 \\
\hline $\mathrm{MCV}, \mu^{3}$ & 110 & 114 & 97 & 103 & 94 \\
\hline Reticulocytes, \% & $7-13$ & $2-3.5$ & 1.0 & 0.6 & 0.6 \\
\hline Spleen & Absent & Intact & Intact & Intact & Intact \\
\hline Coombs (direct) & $\mathrm{Neg}$ & $\mathrm{Neg}$ & Neg & Neg & Neg \\
\hline $\begin{array}{l}\text { Bilirubin, } \\
\text { indirect, } m g / 100 m l \\
\text { Osmotic fragility }\end{array}$ & 0.7 & $0.7-1.0$ & 0.25 & 0.47 & 0.45 \\
\hline $\begin{array}{l}\text { Fresh } \\
\text { Fint }\end{array}$ & Normal & Normal & $\begin{array}{l}\text { Slightly } \\
\text { increased }\end{array}$ & Normal & Normal \\
\hline $\begin{array}{c}24 \mathrm{hr} \\
\text { Serum Fe }\end{array}$ & $\begin{array}{c}\text { Skewed } \ddagger \\
118\end{array}$ & $\begin{array}{c}\text { Skewed } \ddagger \\
170\end{array}$ & $\begin{array}{l}\text { Normal } \\
129\end{array}$ & $\begin{array}{l}\text { Normal } \\
80\end{array}$ & $\begin{array}{l}\text { Normal } \\
96\end{array}$ \\
\hline
\end{tabular}

* Data on the four relatives of the proposita was provided by Dr. Ernest Simon University of New Mexico School of Medicine, Albuquerque.

$\ddagger$ Demonstrates a population of abnormally resistant as well as abnormally fragile cells. 
cell count (chamber count), packed cell aliquots were osmotically hemolyzed in 20 volumes of ice-cold solution containing neutralized disodium ethylenediaminetetraacetate (EDTA) (5 mmoles/liter), 2-mercaptaoethanol (5 mmoles/liter), and glucose (5 mmoles/liter). The lysate was centrifuged at $30,000 \mathrm{~g}$ for $20 \mathrm{~min}$ at $0^{\circ} \mathrm{C}$ to remove particulate stroma and kept at $0-4^{\circ} \mathrm{C}$ subsequently. The measured activity was related to the hemoglobin content of the hemolysate as measured by the cyanmethemoglobin technique. The assay system contained $50 \mu \mathrm{M}$ glycylglycine ${ }^{1} \mathrm{pH} 8.1 ; 5 \mu \mathrm{M}$ glucose; $4 \mu \mathrm{M}$ ATP ${ }^{2}$ (neutral); $0.25 \mu \mathrm{M}$ triphosphopyridine nucleotide $\left(\mathrm{TPN}^{2}\right) ; 7 \mu \mathrm{M} \mathrm{MgCl}_{2}$; glucose 6-phosphate dehydrogenase $(\mathrm{G} 6 \mathrm{PD})^{2} 0.1 \mathrm{U}$, and hemolysate containing 0.75 $1.5 \mathrm{mg}$ of hemoglobin in a volume of $1.0 \mathrm{ml}$ and a final $\mathrm{pH}$ of 7.90. The stock solutions were premixed and the reaction was started by adding hemolysate and monitored on a Zeiss PMQ II spectrophotometer modified for automatic recording with the Zeiss TE converter, a sequential cuvette positioning device, ${ }^{3}$ and a 9.75 inch potentiometric recorder. ${ }^{*}$ The assay activity was linearly related to the quantity of hemolysate over a fourfold range of hemoglobin concentration, remained linear for at least $1 \mathrm{hr}$, and was not significantly affected by doubling or halving any of the substrates, cofactors, or auxillary enzymes. Since no added activity could be obtained, by adding a 10-fold excess of 6 -phosphogluconate dehydrogenase (6PGD) (as compared to hexokinase activity when assayed in the same buffer system), the observed rate probably represents twice the actual hexokinase activity because of the endogenous 6PGD present in the hemolysate. However, the given rates have not been corrected for this. White cell hexokinase activity was measured in the same assay system. White cells were prepared from whole blood, and were frozen and thawed three times with methanol-dry ice and the stroma was removed by spinning at $30,000 \mathrm{~g}$ for $20 \mathrm{~min}$. The red cell contamination was less than $20 \%$ and was considered negligible because of the very high white cell hexokinase activity relative to that in the red cells. The preparation consisted of over $90 \%$ granulocytes. The following enzyme activities were measured in hemolysates from the red cells of the proposita according to the cited methods with minor modifications: glucose 6-phosphate dehydrogenase (G6PD) (9), aldolase (10), glyceraldehyde 3-phosphate dehydrogenase (G3PD) (11), (forward and backward assay) triose phosphate isomerase (TPI) (12), phosphoglycerate kinase (PGK) (backward assay) (11), and pyruvate kinase (PK) (13). With the exception of $\mathrm{PK}$ and TPI (values given in the text) no attempt was made to establish a normal range. Rather, the activity in hemolysates from the patient's cells was compared with that from identically prepared hemolysates from the red cells of a normal control subject. In all cases appropriate blanks were performed and assay activity was verified with commercial enzymes of stated purity (Calbiochem or BoehringerMannheim).

Measurement of glycolytic intermediates. Whole blood was drawn in a heparinized syringe and an aliquot was immediately (within 10-20 sec) deproteinized in two volumes of cold $6 \%(\mathrm{w} / \mathrm{v})$ perchloric acid (PCA). After at least $15 \mathrm{~min}$ on ice, extracts were spun at $12,000 \mathrm{~g}$ for $10 \mathrm{~min}$ and the clear supernatant removed. The samples were neutralized $(\mathrm{pH}$ 6.5-7.0) with potassium bicarbonate (approximately $130 \mu \mathrm{l}$ of a $2 \mathrm{M}$ solution per $\mathrm{ml}$ of extract).

\footnotetext{
${ }^{1}$ Sigma Chemical Co., St. Louis, Mo.

a Boehringer-Mannheim Corp., New York.

${ }^{3}$ Atlantex and Zeiler Corp., Dedham, Mass.

- Texas Instruments, Servo-riter II.
}

Assays for glucose, glucose 6-phosphate (G6P), 3-phosphoglycerate (3PGA), 2,3-diphosphoglycerate (2,3DPG), pyruvate, adenosine diphosphate (ADP), and adenosine triphosphate (ATP) were performed fluorometrically according to the procedures of Lowry, Passoneau, Hasselberger, and Schulz (14). Fructose diphosphate (FDP), glyceraldehyde 3-phosphate (G3P), and dihydroxyacetone phosphate (DHAP), were measured as total triose phosphate (TTP), in a similar manner except that arsenate, glyceraldehyde 3-phosphate dehydrogenase (G3PD) and DPN were substituted for glycerol phosphate dehydrogenase and DPNH. ${ }^{5}$ The assays were quantitated by running simultaneous aqueous standard solutions which had previously been assayed spectrophotometrically. Internal standardization was performed when required by assaying aliquots of the aqueous standard solution in the same tube as the unknown extract after its completion to correct for possible quenching. The proper reaction time was established before each set of assays by recording an unknown sample to completion and a preliminary blank was run to check for contamination of the reagents. Fluorescence was measured in a Farrand model A-3 fluorometer. The results have not been corrected for cell water content. Lactic acid was measured spectrophotometrically with lactic acid kits. ${ }^{\circ}$

Measurement of glycolytic rates. In conjunction with other projects at the Naval Blood Research Laboratory, a system was devised to measure accurately glucose disappearance under carefully monitored conditions. Particular attention was given to the uniform preparation of the cells and maintenance of a constant defined environment during incubation.

The cells to be studied were centrifuged for $7 \mathrm{~min}$ at $1500 \mathrm{~g}$ to remove the buffy coat and the packed cells were resuspended in 50-100 times their volume of buffer containing $\mathrm{Na}^{+} 145$ mmoles/liter, $\mathrm{K}^{+} 5$ mmoles/liter, $\mathrm{Cl}^{-} 125$ mmoles/liter, $\mathrm{HCO}_{8}{ }^{-} 25 \mathrm{mmoles} / \mathrm{liter}$, and glucose as desired at $\mathrm{pH} 7.35$ and room temperature. The cells were then collected in the Szent-Gyorgyi and Blum continuous-flow head for the Sorvall RC-2 centrifuge at $3700 \mathrm{~g}$ and washed with another $1000 \mathrm{ml}$ of the same buffer. By means of modified inlet tubes, the wash stream is delivered near the point of sedimentation and provides agitation during the wash thereby preventing tight packing. This combined dilution and wash can be performed in $15 \mathrm{~min}$ and is an extremely efficient and reproducible way to equilibrate a small volume of cells with the readily diffusible components of the incubation medium. The cells were collected and diluted to the desired hematocrit and bovine serum albumin ${ }^{7}$ was added to a $1 \%$ concentration.

Incubation was performed in spinner flasks ${ }^{8}$ which are water-jacketed, with internal magnetic stirrers and double side-arm ports for convenient sampling. The $\mathrm{pH}$ of the system is automatically controlled by a $\mathrm{pH}$-stat device which is similar in some respects to the systems described by Bishop (15) and Vestergaard-Bogind (16). All of the components are available commercially and easily assembled. The $\mathrm{pH}$ is monitored by an indwelling single probe $(5 \mathrm{~mm}$ diameter, $180 \mathrm{~mm}$ long) electrode, ${ }^{\theta}$ a Radiometer PHM 25 meter, and

\footnotetext{
${ }^{5}$ The author is indebted to Dr. J. V. Passoneau, Washington University School of Medicine, St. Louis, Mo. for this assay method.

- Calbiochem Corporation, Los Angeles, Calif.

${ }^{7}$ Sterile $35 \%$ solution, Nutritional Biochemicals Corporation, Cleveland, Ohio.

${ }^{8}$ Bellco Glass Company, Vineland, N. J.

Ingold No. 14150, from Instrumentation Laboratories, Watertown, Mass.
} 
a potentiometric recorder. Two cylinders, one of compressed air and one of $10 \% \mathrm{CO}_{2}$ in air supply the gas phase. The $10 \% \mathrm{CO}_{2}$ in air stream is routed through thin-walled rubber tubing to an on-off magnetic valve ${ }^{10}$ which is controlled by an automatic titrator. ${ }^{11}$ After passage through flow meters, the gas is mixed under water in a small tube and delivered to the incubation flask by catheter (the aspirator tube from a package of disposable Sahli pipets of Clay-Adams is convenient). Customarily, a constant flow of air is delivered at about $50 \mathrm{cc} / \mathrm{min}$ and, upon demand, the $10 \% \mathrm{CO}_{2}$ in air is added at $150 \mathrm{cc} / \mathrm{min}$ making an approximate $7.5 \% \mathrm{CO}_{2}$-air mixture. If the $\mathrm{pH}$ is to be varied, it can be done quickly by immersing the delivery catheter in the cell suspension and bubbling briefly at low gas flow without causing appreciable hemolysis or affecting steady-state conditions. This system, after equilibration, maintains constant $\mathrm{pH}$ in dilute red cell suspensions within $\pm 0.01 \mathrm{U}$ of the end point setting. To forestall problems of protein poisoning of the glass electrode membrane, two electrodes may be used alternately (with restandardization) although most studies were sufficiently short that only one was necessary. Several of the water-jacketed flasks are arranged in series to a high capacity circulating pump ${ }^{12}$ on a four-place magnetic stirring plate. ${ }^{13}$ The extra vessels serve to pre-equilibrate and standardize the $\mathrm{pH}$ electrode at $37^{\circ} \mathrm{C}$ in a standard buffer and to bring any additives to the same temperature.

In most studies, either 20 or $40 \mathrm{ml}$ of dilute cell suspension (hematocrit $10-20 \%$ ) were incubated in $25-$ or $50-\mathrm{ml}$ siliconized spinner flasks respectively at $\mathrm{pH} 7.40 \pm 0.01$. Because of the large volume of the incubate relative to the sample size, (500 or $1000 \mu \mathrm{l}$ ) and the relatively slow equilibration time, it is possible to remove frequent samples without altering the $\mathrm{pH}$. Samples are removed through a sidearm port after a few seconds of vigorous stirring with 500 or $1000 \mu \mathrm{l}$ constriction pipets ${ }^{14}$ and delivered into $0.5,1.0$, or 2.0 volumes of cold PCA depending on the hematocrit. Subsequently, the samples are handled and analyzed as described above. All of the measured compounds appear to be stable after neutralization, on storage at $-20^{\circ} \mathrm{C}$ except pyruvate (see Lowry et al. [14]) which was measured immediately after it was neutralized.

By adjusting the hematocrit and initial glucose concentration, any desired rate of glucose disappearance may be obtained. To obtain slopes which can be accurately measured in reasonably short incubation periods, the initial glucose concentration must be quite low and an accurate and sensitive assay is required. The extreme sensitivity and linearity of the fluorometric glucose assays over the range of tube concentrations employed in the assays is demonstrated in Fig. 1. This system has several advantages over other methods which can measure glucose consumption at very low levels by assaying the radioactive products which appear during incubation with ${ }^{14} \mathrm{C}$-labeled glucose. It is possible to sample repetitively from the same vessel without terminating the incubation for each experimental point to collect labeled $\mathrm{CO}_{2}$. By analyzing many points, both the linearity and the rate of glucose disappearance may be determined and possible artefacts due to failure to achieve steady-state conditions may be more readily detected.

\footnotetext{
${ }^{10}$ Radiometer MNVI.

11 Radiometer TTT II.

12 Radiometer VTS13.

${ }^{13}$ Bellco Magnistir, Bellco Glass Co., Vineland, N. J.

${ }^{14}$ Carlsberg pipets available from Bolab Inc., Reading, Mass.
}

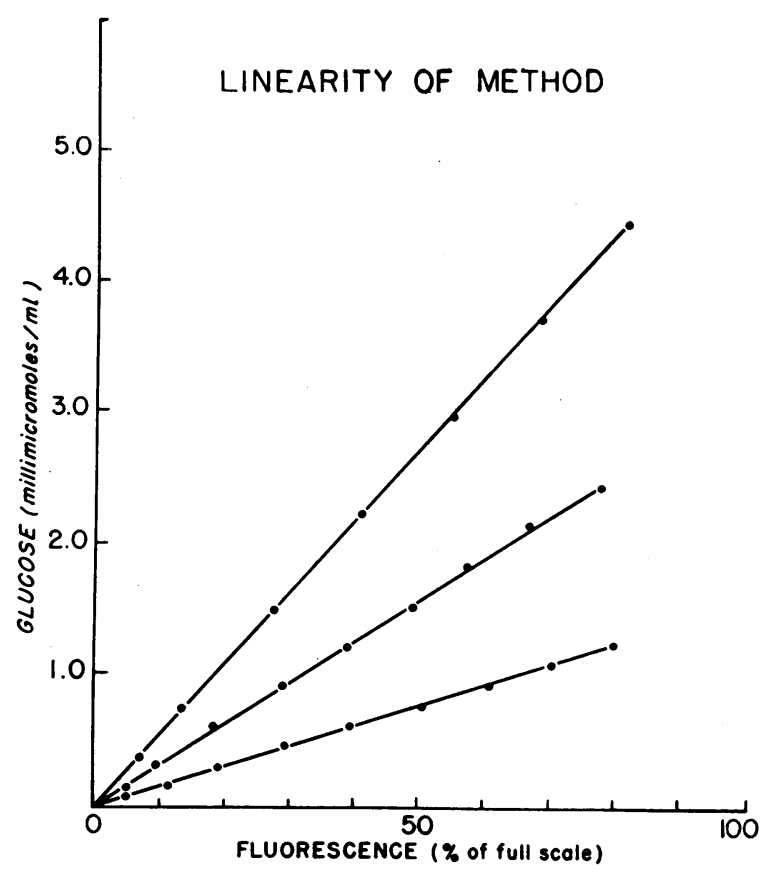

FIGURE 1 Three curves derived by assaying the same series of quantitative dilutions of a glucose stock solution. Each curve represents a different assay sample size $(2,5$, and $10 \mu \mathrm{l}$, from the bottom). Gain settings on the fluorometer are arbitrary and the slopes are not necessarily proportional. The glucose concentrations are those in the assay tube and represent the range of concentrations employed in the assays for glucose as well as other intermediates.

\section{RESULTS}

Glycolytic intermediates in circulating red cells. In Table II, the levels of various glycolytic intermediates in the freshly drawn red cells of this kindred are compared with those from 10 hematologically normal donors. A consistently low value for G6P is apparent in all members which is most marked in the two anemic patients, and was reproduced many times in the proposita. The ATP level was slightly below normal in both patients with overt hemolysis while the ADP level was slightly increased only in the proposita. The level of 2,3-DPG was consistently low in the proposita and was lower than all but one normal blood in her sister. A decreased level of 2,3-DPG has previously been found only in patients with presumed deficiency of 2,3-DPG mutase $(17,18)$ and in certain Dutch patients with high ATP levels (19). The latter patients had slightly elevated hemoglobin values, suggesting that their concentration of 2,3-DPG was not adequate for proper hemoglobin-oxygen equilibrium. The nearly complete degree of compensation of the anemia in the proposita may also be related to her low concentrations of 2,3-DPG and ATP (20). The normal values, as shown in Table II, are comparable to those obtained by Minakami, Suzuki, 
TABLE II

Assays for Red Cell Glycolytic Intermediates*

\begin{tabular}{lcccccc}
\hline Subject & G6P & TTP & DPG & 3PGA & ATP & ADP \\
\hline Normals & $0.029 \pm-0.004$ & $0.013 \pm 0.003$ & $4.39 \pm 0.45$ & $0.047 \pm 0.005$ & $1.40 \pm 0.14$ & $0.177 \pm 0.020$ \\
(n=10) & $0.024-0.034$ & $0.010-0.018$ & $3.44-5.09$ & $0.037-0.053$ & $1.15-1.61$ & $0.124-0.201$ \\
Proposita & 0.013 & 0.011 & 2.4 & 0.045 & 1.08 & 0.211 \\
Sister & 0.010 & - & 3.56 & 0.044 & 1.11 & 0.175 \\
Mother & 0.016 & - & 3.73 & 0.038 & 1.35 & 0.135 \\
Niece & 0.015 & - & 4.10 & 0.038 & 1.38 & 0.137 \\
Niece & 0.019 & - & 4.31 & 0.043 & 1.37 & 0.151 \\
\hline
\end{tabular}

* Expressed as $\mu$ moles $/ \mathrm{ml}$ cells.

$\ddagger$ Mean \pm SD and range.

Saito, and Yoshikawa (21) on similarly prepared samples measured spectrophotometrically. They differ from those reported by Bartlett (22) in that the levels of TTP are much lower, perhaps because of the shorter time interval between drawing and deproteinizing the blood in the present studies.

Enzyme activities. When it was appreciated that the G6P level in the red cells of the proposita was very low, hemolysates were prepared and assayed for hexokinase by the method of Valentine (1). The hemolysate, prepared from saline-washed cells hemolyzed in distilled water, was markedly deficient in hexokinase activity. When the ATP concentration was doubled, there was an increase in activity in the deficient hemolysates but not in hemolysates from normal red cells. Accordingly, the assay was adjusted as described in Methods such that ATP was no longer limiting, an excess of magnesium $\left(\mathrm{Mg}^{++}\right)$over ATP was present and the buffer concentration was raised giving a higher final $\mathrm{pH}$ of 7.9. The hexokinase activities in hemolysates from the proposita and those living relatives available for assay are given in Table III. As originally measured in glucose-free hemolysates, the values appeared to segregate into three ranges of which the lowest was found in the two anemic members, an intermediate range in nonanemic relatives,

TABLE III

Hexokinase Activity in the Kindred

\begin{tabular}{lcc}
\hline \multicolumn{1}{c}{ Subject } & $\begin{array}{c}\text { Hemolyzed without } \\
\text { glucose, mercapto- } \\
\text { ethanol, or EDTA }\end{array}$ & $\begin{array}{c}\text { Hemolyzed with } \\
\text { glucose, mercapto- } \\
\text { ethanol, and EDTA }\end{array}$ \\
\hline Normal range & $0.43-0.58$ & $0.43-0.58$ \\
Proposita & 0.21 & 0.40 \\
Sister & 0.23 & 0.38 \\
Mother & 0.32 & 0.41 \\
Niece & 0.33 & 0.40 \\
Niece & 0.27 & 0.38 \\
\hline
\end{tabular}

* $\mu$ moles/gram hemoglobin per minute, $25^{\circ} \mathrm{C}$, uncorrected for endogenous 6PGD activity. and a normal range. The abnormal requirement for ATP of the hexokinase from the deficient red cells when prepared without glucose is demonstrated in Fig. $2 a$. When glucose, mercaptoethanol, and EDTA were present in the hemolyzing solution, the repeat assay values were uniformly higher and the distinction between anemic, nonanemic, and normal individuals became much less clear. The abnormal ATP requirement for the hexokinase from the proposita disappeared under these conditions as shown in Fig. $2 b$.

The reason for the loss of activity in the hemolysates prepared without glucose was explored in the proposita.
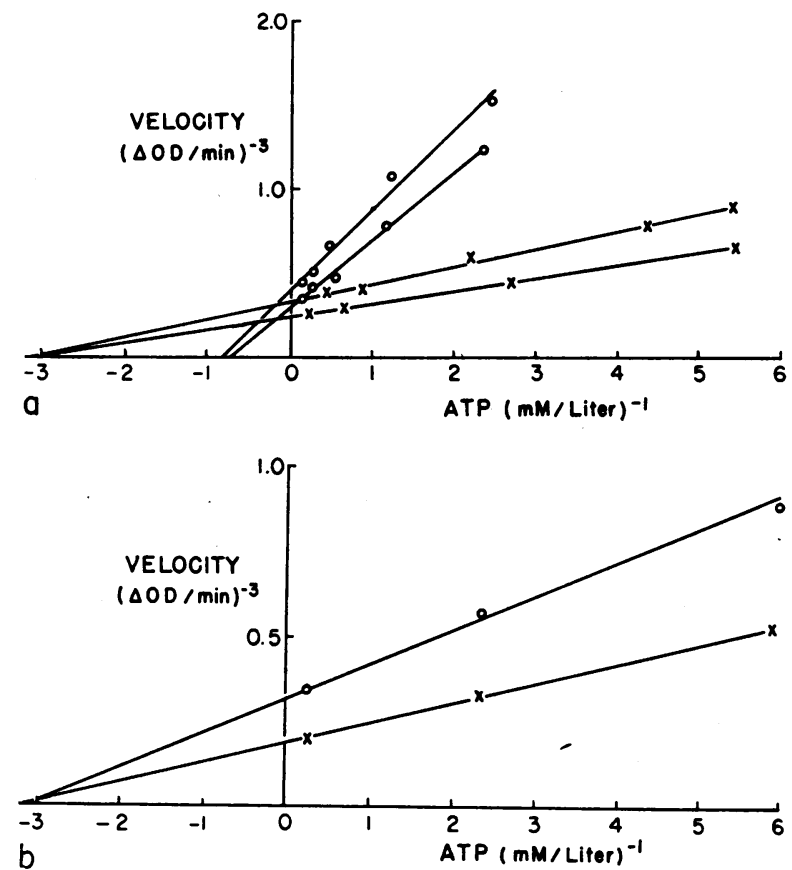

FIgURE 2 Reciprocal plots of reaction rate vs. ATP concentration. (Open circles) proposita; (x) normal. (a) Hemolysates prepared without glucose; (b) hemolysates prepared with glucose. 
TABLE IV

Stability of Hexokinase in Hemolysates

\begin{tabular}{|c|c|c|c|c|c|c|}
\hline \multirow[b]{2}{*}{ Subject } & \multirow[b]{2}{*}{ Hemolyzing solution } & \multicolumn{5}{|c|}{ Hexokinase, $\%$ of maximum } \\
\hline & & Initial & Freeze-thaw & $30 \mathrm{~min}, 45^{\circ} \mathrm{C}$ & 5 days, $2^{\circ} \mathrm{C}$ & 21 days, $2^{\circ} \mathrm{C}$ \\
\hline \multirow[t]{3}{*}{ Control } & Glucose, mercaptoethanol, EDTA & 100 & 100 & 100 & 100 & 94 \\
\hline & Mercaptoethanol, EDTA & 100 & 100 & 87 & 99 & 93 \\
\hline & Water & 100 & 100 & 8 & 96 & 45 \\
\hline \multirow[t]{3}{*}{ Patient } & Glucose, mercaptoethanol, EDTA & 100 & 89 & 75 & 91 & 92 \\
\hline & Mercaptoethanol, EDTA & 99 & 87 & 33 & 94 & 48 \\
\hline & Water & 80 & 47 & 17 & 43 & 31 \\
\hline
\end{tabular}

As shown in Table IV, hexokinase activity is unstable during storage at $2^{\circ} \mathrm{C}$ in aqueous hemolysates, an effect which is apparent immediately in the abnormal hemolysate, but only after 5-21 days in hemolysates from cells of normal individuals. This deterioration is delayed by adding EDTA and 2-mercaptoethanol to the hemolyzing solution and is abolished when glucose is also present. No significant difference in hexokinase activity in normal fresh hemolysates with and without glucose could be found, whereas the presence of glucose, mercaptoethanol, and EDTA resulted in consistently higher activity in fresh hemolysates from the proposita.

That glucose also stabilized normal red cell hexokinase can be demonstrated by mild heating to $45^{\circ} \mathrm{C}$. Glucose, mercaptoethanol, and EDTA, and to a lesser extent 2-mercaptoethanol and EDTA alone, protect normal hexokinase activity for a least $30 \mathrm{~min}$ at this temperature, whereas activity is rapidly lost in simple distilled water hemolysates (Table IV). Glucose alone will fully protect the activity of normal hexokinase under these conditions (not shown).

Assays of white cell hexokinase were performed in the same assay system but at $37^{\circ} \mathrm{C}$ and are shown in Table V. The white cells from the proposita had normal activity when compared with three normal controls. The ratio of white cell activity to red cell activity (also assayed at $37^{\circ} \mathrm{C}$ ) is very high on a per cell basis, approximating 300 to 1 in normal blood. Therefore a 3000 fold excess of red cells over whites would be required to achieve less than $10 \%$ contaminating white cell activity in the red cell assay. This may be particularly difficult to achieve in postsplenectomy patients with elevated reticulocyte and white cell counts, and the removal of white cells by aspiration of the top layer of cells will remove variable numbers of reticulocytes.

Electrophoresis ${ }^{25}$ of both white cell and red cell preparations on agarose medium at $\mathrm{pH} 7.0$ containing glucose, 2-mercaptoethanol, and EDTA did not reveal any abnormal bands of hexokinase activity. The original pa-

${ }^{15}$ Kindly performed by Dr. Gerald E. Bloom, formerly of Children's Hospital Medical Center, Boston, Mass. tient of Valentine et al. was reported to have normal electrophoretic mobility in starch gel at $\mathrm{pH} 8.6$ (23).

PK activity in the proposita was $2.38 \mu$ mole-min per $10^{10}$ red cells (range of 10 normals : $1.16-1.80$ ) and TPI activity was $162 \mu \mathrm{moles} / \mathrm{min}$ per $10^{10}$ red cells (range of 8 normals: $157-181$ ). The activities of G6PD, aldolase, and G3PD were greater than the activities of control hemolysate. PGK activity was $82 \%$ of the control value. However, a significant deficiency of this enzyme in the patient's intact cells is considered very unlikely because of their low concentration of 2,3-DPG. In the only well documented cases of deficiency of PGK, 2,3-DPG was approximately twice normal (24).

Glucose consumption in intact cells. The disappearance of glucose from suspensions of normal red cells and red cells from the proposita was followed in the previously described incubation system. When normal cells (Fig. 3) reach a glucose concentration below approximately $0.05 \mathrm{mmole} / \mathrm{liter}$, they display a characteristic pattern in which G6P falls abruptly and pyruvate begins to accumulate. If sufficiently frequent samples are analyzed, a simultaneous drop in the rate of glucose consumption and lactate production is apparent but in most experiments with normal cells this slight deviation from linearity could not be detected before glucose disappeared completely. ATP, ADP, and TTP levels are stable until after glucose disappears. Under these conditions, the fall in G6P, which precedes glucose exhaustion, serves as a marker for the point at which glucose concentration begins to limit the hexokinase reaction.

TABLE V

White Cell Hexokinase Activity*

\begin{tabular}{rc}
\hline Subject & Activity \\
\hline Proposita & 118 \\
Control 1 & 120 \\
2 & 117 \\
3 & 121 \\
\hline
\end{tabular}

${ }^{*} \mu \mathrm{moles} / \mathrm{min}$ per $10^{10} \mathrm{WBC}, 37^{\circ} \mathrm{C}$. 


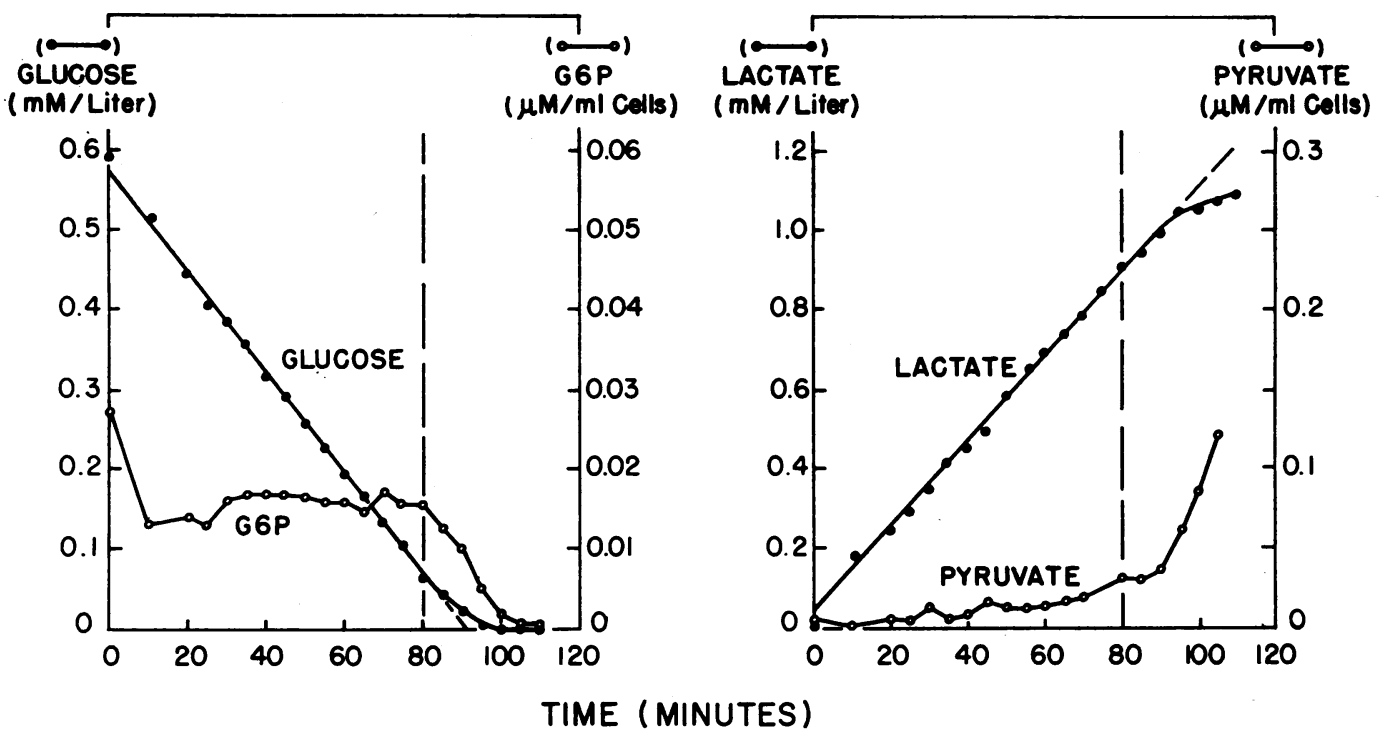

FIGURE 3 Glucose disappearance curve from normal cells incubated under conditions as described in Methods. Dashed line indicated the approximate time of departure from linear disappearance. Simultaneous lactate and pyruvate levels are shown on the right.

When cells from the proposita are similarly incubated (Fig. 4), G6P drops to very low levels and there is abnormal accumulation of pyruvate throughout the incubation. Glucose consumption is linear only to about 0.2 mmoles/liter and then lags, showing a consistent "tail." The rate of pyruvate accumulation increases sharply at this time and lactate production decreases. Maintaining a true steady state in vitro proved very difficult in these cells and ATP and 2,3-DPG decreased slowely throughout the period of incubation in most experiments. It is therefore impossible to establish a priori whether glucose concentration or ATP concentration becomes limiting for the hexokinase reaction as the glycolytic rate slows. To resolve this question, glucose was restored to the

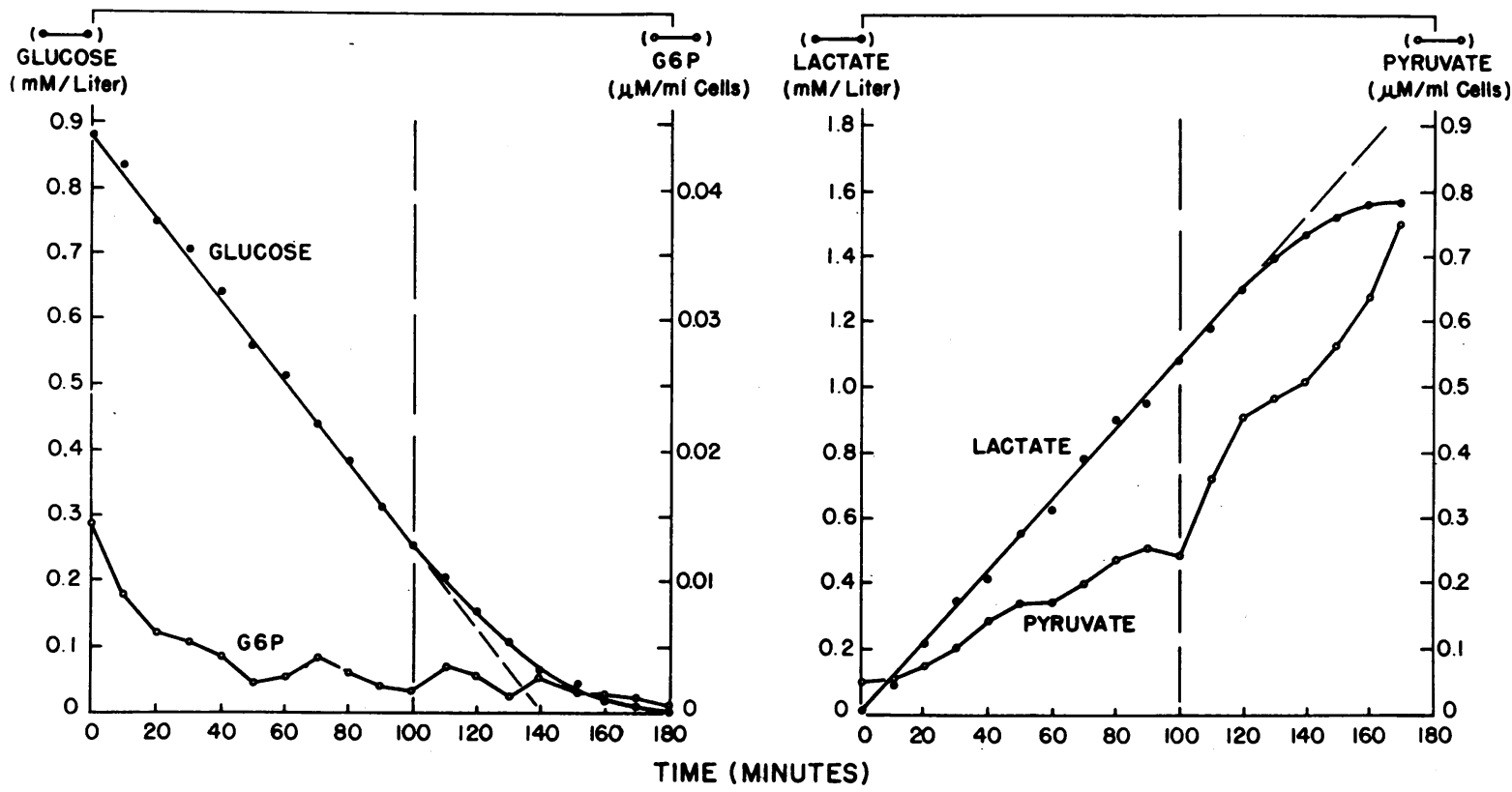

Figure 4 Glucose disappearance curve and lactate and pyruvate accumulation in cells of the proposita. This is a single experiment representative of six similar incubations. 
cells after it had been completely exhausted and the ATP level had fallen to less than $50 \%$ of its initial level (Fig. 5). Glucose consumption resumed at a rate similar to the initial rate indicating that glucose rather than ATP concentration was the likely factor responsible for the "tail" on the disappearance curve.

To examine the possibility that the very low G6P level present throughout the incubation of the patient's cells might influence the shape of the glucose disappearance curve, incubations were performed with normal red cells under conditions inducing a drop in G6P level. As shown in Fig. 6, normal linear disappearance was noted in the presence of methylene blue $(6 a)$, despite the lowering of G6P level induced by this glycolytic stimulant. Similarly, the red cells of a patient with hereditary elliptocytosis, with a reticulocyte count of $12 \%$ (similar to that of the proposita) maintained a constant rate of glucose utilization without measurable slowing at low concentrations of glucose (Fig. $6 b$ ). The steady-state level of G6P in these cells was increased in contrast to the abnormal cells.

Because of the difficulty in achieving steady-state conditions during incubation of the cells from the patient, the absolute glycolytic rate is somewhat uncertain. Using the linear portion of the curve or initial rates, the consumption ranged from 1.3 to 1.6 ( $\mu \mathrm{moles} / \mathrm{ml}$ of cells per hr) compared with a normal steady-state rate of 1.6-1.8. This slight under-utilization of glucose is amplified by comparison with the elliptocytic cells of roughly comparable age which utilized glucose at 3.67 $\mu$ moles $/ \mathrm{ml}$ of cells per hr.

\section{DISCUSSION}

Several lines of evidence, obtained from studies of both intact cells and hemolysates, have been presented which

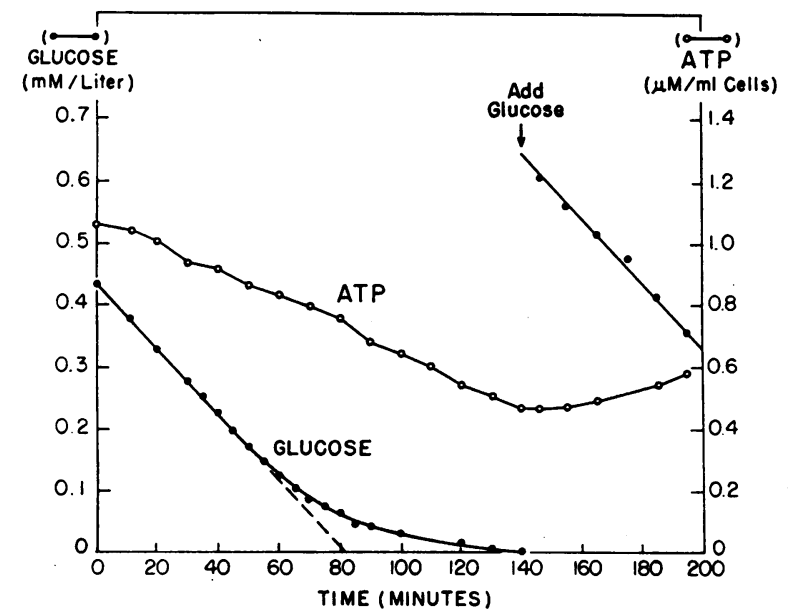

FIgUre 5 Glucose disappearance and simultaneous ATP concentrations in cells of the proposita.
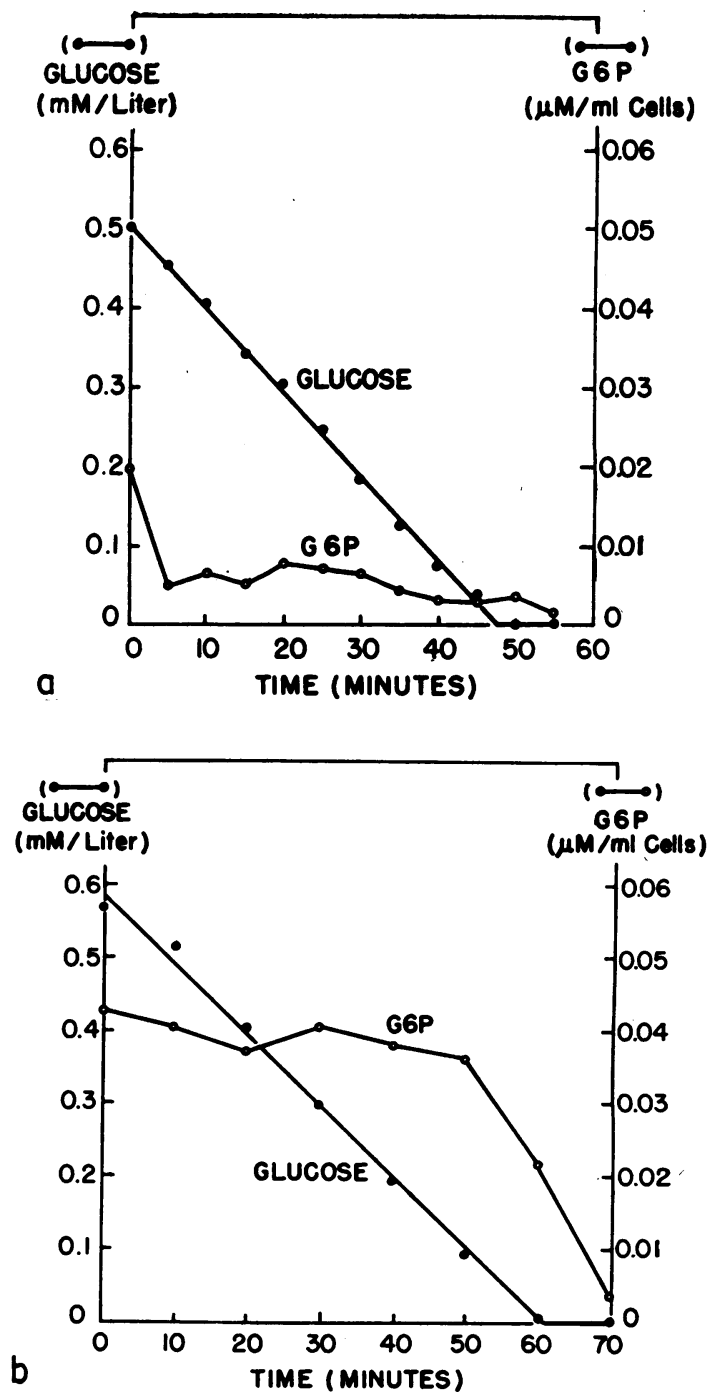

FIgURE 6 Glucose disappearance and simultaneous G6P concentration. (a) Normal cells with $0.001 \%$ methylene blue (final concentration) added at time zero. (b) Cells from a patient with hereditary elliptocytosis and $12 \%$ reticulocytes.

indicate that hexokinase activity is deficient in the red cells of various members of this family. The first involves the demonstration of diminished G6P concentration in the circulating blood of all of the members tested. Interpretation of abnormal concentrations of intermediates is complex and they should be considered a necessary but not sufficient criterion for the presence of an enzymatic lesion in the glycolytic chain. The required assumption is that a significant discrete lesion in the glycolytic pathway will show a "crossover" point (25) with accumulation of proximal and decrease of distal intermediates adjacent to the affected enzyme. Difficulties in the application of this theorem to normal glycolysis have recently been discussed by Scrutton and 
Utter (26). Hexokinase is a particularly difficult point at which to apply "crossover" reasoning for several reasons. The first is that intracellular glucose concentration, because of the extremely high capacity of the glucose transport system in the red cell membrane, reflects alterations in blood glucose rather than changes in hexokinase activity. Therefore accumulation of the substrate of the reaction cannot be demonstrated. Secondly, the concentration of G6P is controlled not only by hexokinase but also by G6PD and PFK, and a secondary stimulation of these enzymes can lower the G6P levels. The normal to low concentration of the more distal intermediates is useful evidence against the presence of a defective glycolytic enzyme other than hexokinase but does not exclude hemolysis from other causes. It should be emphasized that the levels of G6P and TTP are subject to very rapid change after blood is drawn. Therefore a neutral anticoagulant and immediate deproteinization are mandatory. White cell and platelet contribution to the levels of glycolytic intermediates is negligible and attempts to remove them will preclude any consistent results with these intermediates.

It is quite possible that G6PD and PFK are stimulated in the cells of the proposita. Normal cells respond to the resultant drop in G6P concentration with increased glucose consumption because G6P, by inhibiting hexokinase, exerts a major regulatory role in the control of glycolytic rate (27). Therefore the failure of the abnormal cells to demonstrate an increased glycolytic rate appropriate to the low G6P concentration indicates deficient hexokinase activity regardless of the state of G6PD or PFK. Hexokinase is also inhibited by a fall in the ATP/ADP ratio. However, in the experiment depicted in Fig. 5, a fall from 4.5 to 1.1 in the ATP/ADP ratio did not further limit glycolytic rate when glucose was restored to the medium. Furthermore, G6P concentration was also decreased in the family members who had normal ATP/ADP ratios.

Accumulation of pyruvate is a sensitive indicator of a slowing of the initial glycolytic reactions. The source of pyruvate is the 2,3-DPG pool which is prevented from going all the way to lactate by the shift in the ratio of reduced to oxidized DPN consequent to slowing of the G3PD reaction which in turn limits the $\mathrm{LDH}$ reaction. It is thus significant that the patient's cells lost 2,3-DPG and accumulated abnormal amounts of pyruvate during incubation. This glycolytic pattern is characteristic of incubation under acid conditions and with substrate exhaustion, and would be expected with a primary defect in hexokinase activity. It is also apparent that the concentrations of these distal intermediates such as pyruvate and 3FGA are determined by the response of distal enzymes and that a uniform decrease in all intermediates distal to a defective glycolytic enzyme would not be expected. Because of the occurrence of these secondary "crossover" points the levels of representative compounds along the entire glycolytic chain must be measured in order to draw conclusions as to abnormalities at any given site. Such studies have not been previously reported for fresh blood in patients with glycolytic enzyme deficiencies.

The exact inheritance of this condition cannot be definitely determined, but it is probable that it is transmitted as an autosomal recessive as are almost all of the other enzyme lesions in the glycolytic pathway. The family members with normal hematocrits and reticulocyte counts were not studied sufficiently to rule out occult hemolysis but are probably hematologically normal heterozygotes. The abnormally low G6P level in these individuals serves as a particularly useful marker and correlates better with clinical severity than the enzyme activity when measured under optimal conditions. The low G6P level may allow their hexokinase to function at an adequate rate. There have been no prior reported studies of glycolytic compounds in fresh blood of heterozygous patients with "intermediate" deficiency of other glycolytic enzymes to see whether this is a general phenomenon.

The abnormal dependence of glycolytic rate on glucose concentration provides further indication that an aberrant hexokinase is present in the cells of the proposita. By amplifying the lowest part of the glucose disappearance curve and using a drop in G6P concentration as a marker, the independence of hexokinase rate from glucose concentration for normal cells could be confirmed down to at least $0.05 \mathrm{~mm} /$ liter glucose. By contrast, a consistent lag in glucose utilization by the affected cells occurred below about $0.2 \mathrm{mmole} / \mathrm{liter}$ glucose, which was independent of ATP level and reversible with an increase in glucose concentration. No further increment in glycolytic rate could be obtained at $5 \mathrm{~mm}$ glucose and it is improbable that the decreased utilization at very low levels has any pathologic significance. Attempts to document an abnormal Michaelis constant for glucose in hemolysates from the patient's cells were precluded by the marked aberration in ATP requirement and apparently irreversible decrease in $\mathrm{V}_{\max }$ which were induced when the enzyme was unsaturated with glucose. These artifactual anomalies, presumably due to partial denaturation of a labile enzyme, demonstrate some of the hazards inherent in the kinetic analysis of mutant enzymes. Studies in intact cells under sufficiently refined conditions may give a clearer picture of the metabolic lesion.

The lability of this enzyme in unprotected hemolysates also suggests that an abnormal hexokinase is associated with the hemolytic propensity of the affected cells. A similar, although latent instability of normal red cell 
hexokinase can be demonstrated by mild heating of hemolysates prepared in the absence of glucose, which is abolished if glucose is restored at any time before heating. This behavior is characteristic of the type II isoenzyme of hexokinase from other tissues (28), although the major component of red cell hexokinase has the electrophoretic mobility of the type I isoenzyme (29-31). These findings make it unlikely that the protective effect of glucose in hemolysates is mediated by reduced gluthathione, since this compound cannot be regenerated with glucose in unfortified hemolysates. Rather, the stabilization by substrate and partial protection afforded by the sulfhydryl compound mercaptoethanol suggest that a change in tertiary or quaternary structure is induced by substrate binding which renders the protein less favorable for oxidative attack at its reactive sulfhydryl group. Protection of enzyme activity against thermal, oxidative, or proteolytic denaturation by substrate binding or in the presence of an allosteric modifier has been demonstrated for many enzymes including hexokinase $(28,32)$. The possible significance of this lability in intact cells in vivo where the cells are saturated with glucose and reduced gluthathione is at normal levels is uncertain. The enzyme is not apparently rapidly denatured in intact cells of the proposita when they were washed free of glucose since full activity was retained if the cells were subsequently hemolyzed with glucose mercaptoethanol and EDTA. However, the poor performance of the cells during incubation, with failure to maintain the levels of ATP, 2,3-DPG, and G6P found in vivo, indicates that hexokinase function may have been altered by the manipulations even though glucose was constantly present.

The possibility has been considered that the demonstrable inipairment of hexokinase activity in this patient's intact cells and its lability in hemolysates may reflect some abnormal oxidative stress. Hexokinase from several mammalian tissues, including human erythrocytes, are inhibited in the presence of certain disulfides and this inhibition is considerably relieved by the presence of glucose (32). It has been shown that in the presence of certain unstable hemoglobins, mixed disulfide formation occurs between reduced gluthathione and the reactive sulfhydryl groups of the $\beta$-chains of hemoglobin (33). In the subsequent unfolding and precipitation of these hemoglobins, additional reactive $\mathrm{SH}$ groups are exposed which form disulfide linkages with membrane (34) and presumably might also affect the activity and stability of $\mathrm{SH}$ enzymes such as hexokinase. Metabolic studies of red cells containing unstable hemoglobins have shown a stimulation of the HMP shunt and marked lability of ATP $(35,36)$. However, in both Köln and Sabine hemoglobinopathies the glycolytic rate of red cells incubated in vitro was significantly increased, in- dicating that hexokinase was not significantly affected. The decreased glycolysis, the absence of Heinz bodies in the circulating red cells after splenectomy, and the normal level of reduced gluthathione provide evidence against the presence of an unstable hemoglobin variant in this case.

\section{ACKNOWLEDGMENTS}

I gratefully acknowledge the following people's contributions to these studies: C. R. Valeri, LCDR, USNR, Naval Blood Research Laboratory, Chelsea, Mass., for his support of the investigations; Charles Herdegen, HM1 USN and Melody French, Naval Blood Research Laboratory, for technical assistance; Dr. Willis Keene, formerly of the Lahey Clinic, Boston, for referral of the proposita; Dr. Ernest Simon, University of New Mexico School of Medicine, Albuquerque, for the hematologic work-up on the family members and for sending material for assay on these individuals; Dr. Gerald E. Bloom, formerly of the Childrens Hospital Medical Center, Boston, for electrophoresis of the hexokinase; Dr. J. V. Passoneau, Washington University, St. Louis, Mo., for making available certain of the assay procedures; and Dr. Ward Noyes and Dr. Hyram Kitchen, Gainesville, Fla., for review of the manuscript.

This work was supported in part by grants T1-AM-5391 and HE-07652 from the National Institutes of Health.

\section{REFERENCES}

1. Valentine, W. N., F. A. Oski, D. E. Paglia, M. A. Baughan, A. S. Schneider, and J. L. Naiman. 1967. Hereditary hemolytic anemia with hexokinase deficiency. N. Engl. J. Med. 276: 1.

2. Kirkman, H. N., C. Kidson, and M. Kennedy. 1968. Variants of human glucose-6-phosphate dehydrogenase. Studies of samples from New Guinea. In Hereditary Disorders of Erythrocyte Metabolism. E. Beutler, editor. Grune \& Stratton Inc., New York. 126.

3. Paglia, D. E., W. N. Valentine, M. A. Baughan, D. R. Miller, C. F. Reed, and R. O. McIntyre. 1968. An inherited molecular lesion of erythrocyte pyruvate kinase. Identification of a kinetically aberrant isozyme associated with premature hemolysis. J. Clin. Invest. 47: 1929.

4. Miwa, S., T. Nishina, H. Ohyama, and T. Kumatori 1968. Congenital hemolytic anemia due to functionally abnormal pyruvate kinase. Abstracts of the XIIth Congress of the International Society of Hematology, New York. 117.

5. Keitt, A. S. 1966. Pyruvate kinase deficiency and related disorders of red cell glycolysis. Amer. J. Med. 41: 762.

6. Loos, J. A. 1968. In Hereditary Disorders of Erythrocyte Metabolism. E. Beutler, editor. Grune \& Stratton Inc., New York. 247.

7. Keitt, A. S. 1968. Hemolytic anemia with impaired hexokinase activity. Clin. Res. 16: 306. (Abstr.)

8. Chapman, R. G., M. A. Hennessey, A. M. Waltersdorph, F. M. Huennekens, and B. W. Gabrio. 1962. Erythrocyte metabolism. V. Levels of glycolytic enzymes and regulation of glycolysis. J. Clin. Invest. 41: 1249.

9. Beutler, E., C. K. Mathai, and J. E. Smith. 1968. Biochemical variants of glucose-6-phosphate dehydrogenase giving rise to congenital nonspherocytic hemolytic disease. Blood. 31: 131.

10. Schrier, S. L. 1963. Studies of the metabolism of human erythrocyte membranes. J. Clin. Invest. 42: 756. 
11. Schrier, S. L. 1966. Organization of enzymes in human erythrocyte membranes. Amer. J. Physiol. 210: 139.

12. Schneider, A. S., W. N. Valentine, M. Hattori, and H. L. Heins, Jr. 1965. Hereditary hemolytic anemia associated with triose phosphate isomerase deficiency. $N$. Engl. J. Med. 272: 229.

13. Tanaka, K. R., W. N. Valentine, and S. Miwa. 1962. Pyruvate kinase $(\mathrm{PK})$ deficiency hereditary nonspherocytic hemolytic anemia. Blood. 19: 267.

14. Lowry, O. H., J. V. Passoneau, F. X. Hasselberger, and D. W. Schulz. 1964. Effect of ischemia on known substrates and cofactors of the glycolytic pathway in brain. J. Biol. Chem. 239: 18.

15. Bishop, C. 1962. Maintenance of ATP level of incubated human red cells by controlling the $\mathrm{pH}$. Transfusion (Philadelphia). 2: 408.

16. Vestergaard-Bogind, B. 1962. Automatic $\mathrm{pH}$ regulation of cell suspensions by a gasometric pH-stat. Scand. J. Clin. Lab. Invest. $14: 461$.

17. Prankerd, T. A. J. 1959. The nature of erythrocyte defect and the haemolytic mechanism in hereditary spherocytosis and hereditary nonspherocytic haemolytic anemias. In Hamolyse und Hamolytische Erkrankungen, 7th Freiburger Symposium (1959). 136-142. Schubothe (Hrsg). Berlin-Gottinger-Heidelberg. Springer-Verlag. 1961.

18. Schröter, W. 1965. Kongenitale nichtsphärocytäre hämolytische Anämie bie 2,3-DiphosphoglyceratmutaseMangel der Erythrocyten im frühen Säuglingsalter. Klin. Wochenschr. 43: 1147.

19. Loos, J. A., H. K. Prins, and C. Zurcher. 1968. Elevated ATP levels in human erythrocytes. In Hereditary Disorders of Erythrocyte Metabolism. E. Beutler, editor. Grune \& Stratton Inc., New York. 280.

20. Bellingham, A. J., and E. R. Huehns. 1968. Compensation in haemolytic anaemias caused by abnormal haemoglobins. Nature (London). 218: 924.

21. Minakami, S., C. Suzuki, T. Saito, and H. Yoshikawa. 1965. Studies on erythrocyte glycolysis. I. Determination of the glycolytic intermediates in human erythrocytes. J. Biochem. (Tokyo). 58: 543.

22. Bartlett, C. R. 1968. Phosphorus compounds in the human erythrocyte. Biochim. Biophys. Acta. 156: 221.

23. Malone, J. I., A. I. Winegrad, F. A. Oski, and E. W. Holmes, Jr. 1968. Erythrocyte hexokinase isoenzyme patterns in hereditary hemoglobinopathies. N. Engl. J. Med. 279: 1071.
24. Valentine, W. N., H. Hsieh, D. E. Paglia, H. M. Anderson, M. A. Baughan, E. R. Jaffé, and O. M. Garson. 1969. Hereditary hemolytic anemia associated with phosphoglycerate kinase deficiency in erythrocytes and leukocytes. N. Engl. J. Med. 280: 528 .

25. Chance, B., J. Higgins, W. Holmes, and C. M. Connelly. 1958. Localization of interaction sites in multicomponent transfer systems. Theorems derived from analogues. Nature (London). 182: 1190.

26. Scrutton, M. C., and M. F. Utter. 1968. The regulation of glycolysis and gluconeogenesis in animal tissues. Annu. Rev. Biochem. 37 : 249.

27. Rose, I. A., and E. L. O'Connell. 1964. The role of glucose 6-phosphate in the regulation of glucose metabolism in human erythrocytes. J. Biol. Chem. 239: 12.

28. Grossbard, L., and R. T. Schimke. 1966. Multiple hexokinases of rat tissues. Purification and comparison of soluble forms. J. Biol. Chem. 241: 3546.

29. Holmes, E. W., Jr., J. I. Malone, A. I. Winegrad, and F. A. Oski. 1967. Hexokinase isoenzymes in human erythrocytes: association of type II with fetal hemoglobin. Science (Washington). 156: 646.

30. Kaplan, J. C., and E. Beutler. 1968. Hexokinase isoenzymes in human erythrocytes. Scicnce (Washington). $159: 215$.

31. Schröter, W., and W. Tillmann. 1968. Hexokinase isoenzymes in human erythrocytes of adults and newborn. Biochem. Biophys. Res. Commun. 31: 92.

32. Nesbakken, R., and L. Eldjarn. 1963. The inhibition of hexokinase by disulfides. Biochem. J. 87: 526 .

33. Jacob, H. S., M. C. Brain, J. V. Dacie, R. W. Carrell, and $H$. Lehmann. 1968. Abnormal haem binding and globin SH group blockade in unstable haemoglobins. Nature (London). 218: 1214.

34. Jacob, H. S., M. C. Brain, and J. V. Dacie. 1968. Altered sulfhydryl reactivity of hemoglobins and red blood cell membranes in congenital Heinz body hemolytic anemia. J. Clin. Invest. 47: 2664

35. Grimes, A. J., A. Meisler, and J. V. Dacie. 1964. Congenital Heinz body anemia. Further evidence on the cause of Heinz body production in red cells. Brit. J. Haematol. 10: 281 .

36. Schneider, R. G., S. Ueda, J. B. Alperin, B. Brimhall, and R. T. Jones. 1969. Hemoglobin sabine beta 91 (F 7) Leu $\rightarrow$ pro. An unstable variant causing severe anemia with inclusion bodies. N. Engl. J. Med. 280: 739. 